\title{
The Implementation of VCT (Value Clarification Technique) Model in Improving Students' Responsibility Character on Environment in Indonesia
}

\author{
(A Case Study in State Senior High Schools in Solok Regency)
}

\author{
Dahliar \\ Student of Geography Education Master Program, \\ Faculty of Social Sciences, Universitas Negeri Padang, INDONESIA \\ Email: dahliar90@gmail.com
}

\begin{abstract}
The purpose of this research was to develop students' responsibility character through the implementation of VCT learning and study its effect on students'concern towards enviromental hygiene in state senior high school of Solek Regency. This research employed mixed method research. The data was collected through observation, interview and documentation. To analyze the data, the researcher used simple percentage analysis followed by data reduction, interpretation and conclusion. The result of the study showed that the implementation of learning by using VCT learning model in developing the character of responsibility has been going well. In State Senior High School 1 of Pantai Cermin, students' responsibility character was going into start to develop criteria while in State Senior High School 1 of Lembah Gumanti it was categorized as culturized. The development of resposibility character in both schools was affected by schools' condition and location.
\end{abstract}

Keywords: Responsibility Character, Environment

\section{Introduction}

Education is aimed to generate educated and noble society who are aware of harmonious life and tolerance to pluralism, and create a global democratic society. It is relevant with the purpose of national education stated in Constitutions Number 20 Article year 2003 National educational system. Noble character is an important aspect in national life. The development of noble character can be achieved through formal and informal education. Formal education consists of primary, secondary and tertiary level of education. The development of noble character will be affected by one's character. Without a good character, someone could do whatever they please and hurt other people. The importance of character suggests parents or school to begin implementing character based education as early as possible for the sake of creating virtous human resources who have strong character, noble heart and a steady. Character building is very important to establish a safe, just and properous life of a citizen. Therefore, Authorities such as school, related govenrment, society and famility should pay special attention on character building. Character building is a process of developing one's character which will be influenced by family, school, and society. School is a strategic place for developing student's character so that the students will have a good personality. One of characters that should be developed is a caring attitude towards the environment. By developing this character can keep the environment clean, safe and well maintain whether it is in house, school or the environment in which the indivual is located.

The purpose of Geography education can not be separated from national educational purposes, namely "to develop society who have character of Pancasila, a healty human body and spirit, knowledge and 
skill, are creativity and responsibility, democratic attitude, tolerance, are able to develop high intellegence and have vitous noble character, love fellow human as stated in Constitutions 1945". Character based education is applied in all evironments that surround learners for example, familiy, school and society. Environment is a place of full experience that will influence the development of child's culture. Therefore, all environments that surround the children should have a culture that can build their character, espicially in an academic environment which will develop their morals. Character based education needs values internalization. In other words to instill character, children need to be used to the values. For example, every family activity should must contain character values. Children's development pattern should also be observed by parent so the children will not be shock due to the imcompatibility between created condition and character values and children's ability to internalize the values.

In the preliminary research, the researcher found the degradation of students' character values like responsibility, honesty, discipline, firmness/persistence and othersin State Senior High Schools in Solok Regency. Students were found to do littering, were not concerned with enviromental hygiene, come late to school, be undisciplined in dressing, and scribbling the wall with dirty words. Hygiene was the main problem in the school. Students' concern for school cleanliness was decreasing. it was proved by the amount of garbage in school environment whether it is inside or outside of classroom. Cleanliness reflects one's personality. Indifference to the school enviromental hygiene, especially in the classroom will negatively affect learning effectiveness and create an uncomfortable and unsightly environment and vice versa. Students' concern to enviromental hygiene, will be beneficial for learning effectiveness and create a comfortable learning environment. This problem should be noted and solved throughraising students' awareness and attention on school enviromental hygiene, especially classroom hygiene which is usually affected by several factors such as environmental influences, students' responsibility character toward classroom environment and other factors. Based on the problems above, the main cause of students' low character values in state senior high schools in Solok Regency was the absence of character-integrated learning activities in the classroom. Teachers were only focus on improving students' knowledge. moreover, the majority of teachers used One traditional teaching methos such as lecturing and task-based teaching method dan rarely implemented teaching-learning model in the classroom. Therefore, a solution is by implementing model and techniques and teaching-learning activities. Using an appropriate learning model and integrating the character values into learning process will develop students' character values.

Various learning models can be implemented in the classroom. one of models applied in geography classroom is VCT (Value Clarification Technique). VCT is one of the learning techniques that can meet the goal of value based education achievement. VCT helps students to achieve and decide good values when facing a problem through a process of analyzing students' existed values. (Taniredja, 2011). According to Djahiri (1985) VCT will beneficial for effective learning because 1) Able to guide and instilling moral values to the students, 2) Enable the students to clarify and dig more information from the learning materials so the teacher will be able to elaborate the moral values, 3) It enable the teacher to clarify and evaluate the quality of students' moral value, 4) It encourages, involves and guides the students to develop their potential especially their potential behaviors, 5) It enables the teacher and students to take a lesson from one's life, 6) It enables the teacher and students to avoid, negate the intervention of unneeded values, and combine various moral values into value system and into someone, 7) It gives a picture of a moral values that should be accepted, guides and motivated the students to have worthy life and have high morals.

\section{Method}

Based on the problems, the purpose of this research is to develope students' responsibility character by using VCT learning models and its effect on students' awareness towards school environmental hygiene 
in state senior high schools in Solok regency. This research employed a mixed method research. The techniques of data collection were observation, interview and documentation. then, the data was analyzed through simple percentage analysis followed by data reduction, data interpretation and conclusion.

\section{Results and Discussion}

This research was conducted based on the following steps: (1) Prearing Lesso Plan (RPP) for two meetings. Lesson Plan describe the scenario of teaching and learning process and the steps of VCT implementation. There were 6 six steps of VCT learning model, namely: a) Determining the stimulus, b) Presenting stimulus through demonstration, reading or asking students to do the demonstration, c) detemining position/choice/opinion, d) examining the reason, e) conclusion and briefing, f) follow-up and conclusion. steps of VCT learning is related to learning techniques. VCT techniques used in this research is inquiry value technique which is by giving random questions to the students. By doing so, the students train to think critically, analitically, and develop students curiousity, and students are able to formulate hypohesis or assumption and try to reveal the existing and deviating value or value system; (2) Selecting and determining media related to the problem to be solved or discussed by students in groups.In cycle I media used is Power Point Media that is displayed by using projector; (3) Designing handouts and worksheet (LKS) for students.Handouts and LKS were made for each meetings, there were two handouts and LKS. The first one was related to the materials about types of family taxes $(\mathrm{PPh})$. The second one was about types of famility taxes; (4) Deciding students group. In cycle 1 the teacher divided students into 5 discussion groups, one gorup was consisted of 5-6 students. The group memberswererandomly selected by the teacher; (5) Prepare the observation instrument. Observation Instrument was in the form of observation sheet prepared as a tooltocolect the data of learning process.prepared observation sheet was used to observe the development of students' honesty characters and student responsibilities during the learning process using VCT model. The character of the responsibilities observed were, a) throwing the garbage in its place, b) picking up scattered rubbish, c) do the dutyl; (6) Determining and contactingthe collaborators who will assist researcher in observing the learning activities. Collaborators wereaskedtomake field notes and fill in observation sheets. there were two collaborators selected so that this research can obtained the desired data from observation. collaborators were Geography teacher Septra Yosilfa, S.Pd and counselling teacher Gusnawarni, S.Pd. Mrs Gusnawarni was chosen due to her experiences in understanding students' character in the school.

Based on the steps above this research was conducted in two state senior highschools in Solok, namely that SMA Negeri 1 Lembah Gumanti and SMA Negeri 1 Pantai Cermin. Based on the data from teacher's, collaborators' obsevation, and teacher's field notes, the implementation of VCT learning model in developing students responsibility character and its effect on school environmental hygiene is dispaleyed as follow:

Table 1. Scores of Responsibility Character in Preliminary Observation

\begin{tabular}{|c|c|c|c|}
\hline Name of School & Indicator to be observed & Criteria & Percentage $(\%)$ \\
\hline \multirow{3}{*}{ 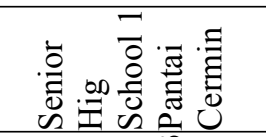 } & Throw garbage in its place & BT & $27,90 \%$ \\
\hline & Pick up scattered rubish & BT & $25,00 \%$ \\
\hline & Do the duty & BT & $34,60 \%$ \\
\hline \multirow{3}{*}{ 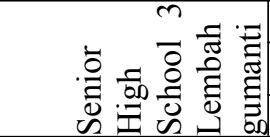 } & Throw garbage in its place & MT & $47,10 \%$ \\
\hline & Pick up scattered rubish & BT & $35,60 \%$ \\
\hline & Do the duty & MT & $54,80 \%$ \\
\hline
\end{tabular}

Source : Primary data processing 
Table 2. Predicates and Criteria of Character Achievement Assessment

\begin{tabular}{|l|l|l|l|}
\hline \multicolumn{2}{|l|}{ Individual Achievement } & \multicolumn{2}{l|}{ Classical Achievement } \\
\hline Score & Predicate & Precentage & Criteria \\
\hline $1-3$ & Poor/K & $20-40 \%$ & not yet visible /BT \\
$4-6$ & Fair/C & $41-60 \%$ & visible /MT \\
$7-9$ & Good/B & $61-80 \%$ & start to develop /MB \\
$10-12$ & Very Good/SB & $81-100 \%$ & Culturized/MK \\
\hline
\end{tabular}

Table 2 is the recapitulation data obtained from preliminary research of students' responsibility character. It shows that responsibility character of students in State Senior High School 1 Pantai Cermin was considered as "not yet visible" in criteria 1, 2, and 3. Responsibility character of students in State Senior high School 1 in Lembah Gumantiwas categorized as "not yet visible" (criteria 2) and "visible" (criteria 1 and 3 ).

Table 3. Scores of Responsibility Character after Observations

\begin{tabular}{|c|c|c|c|}
\hline $\begin{array}{l}\text { Name of } \\
\text { School }\end{array}$ & $\begin{array}{l}\text { Character Indicators to be } \\
\text { observed }\end{array}$ & CRITERIA & Percentage (\%) \\
\hline \multirow{3}{*}{ 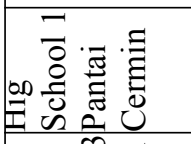 } & Throw garbage in its place & MB & $72,50 \%$ \\
\hline & Pick up scattered rubish & MB & $71,20 \%$ \\
\hline & Do the duty & MB & $71,20 \%$ \\
\hline \multirow{3}{*}{ 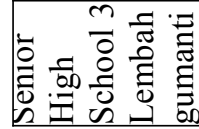 } & Throw garbage in its place & MB & $77,90 \%$ \\
\hline & Pick up scattered rubish & MB & $72,10 \%$ \\
\hline & Do the duty & MK & $84,60 \%$ \\
\hline
\end{tabular}

Source : Primary Data Processing

Table 4. Predicates and Criteria of Character Achievement Assessment

\begin{tabular}{|l|l|l|l|}
\hline \multicolumn{2}{|l|}{ Individual Achievement } & \multicolumn{2}{l|}{ Classical Achievement } \\
\hline Score & Predicate & Percentage & Criteria \\
\hline $1-3$ & poor/K & $20-40 \%$ & not yet visible /BT \\
$4-6$ & Fair/C & $41-60 \%$ & visible /MT \\
$7-9$ & Good/B & $61-80 \%$ & start to develop /MB \\
$10-12$ & Very Good /SB & $81-100 \%$ & Culturized/MK \\
\hline
\end{tabular}

The Recapitulation of observation sheet of students' responsibility character after VCT implementation showed that in State Senior High School 1 Pantai Cermin, students' responsibility character of indicator 1, 2, and 3 was categorized as "start to develop". Meanwhile, students' responsibility character in State Senior High School 1 Lembah Gumanti, indicator 1 and 2 was categorized as "start to develop" and indicator 3 was "culturized".

\section{Conclusion}

The implementation of learning by using VCT learning model in developing the character of responsibility has been going wellespecially in State Senior High School 1 Pantai Cermin, the character was categorized as "start to develop" criteria. Meanwhile students' responsibility character in State Senior High School 1 Lembah Gumanti was categorized as "culturized". The development of responsibility character of the two schools was affected by school condition and location. 


\section{Reference}

Ani, Siti Anisah. (2016). Pendekatan Pembelajaran Analisis Nilai Untuk Meningkatkan Pemahaman Konsep dan Sikap Kepedulian Sosial Siswa Pada Mata Pelajaran Ilmu Pengetahuan Sosial. Jurnal

Arikunto, S. (2002). Prosedur Penelitian Suatu Pendekatan Praktek. Jakarta: Rineka Cipta

Dimyati. (2003). Strategi Belajar Mengajar. Jakarta: Departemen Pendidikan Dan Kebudayaan Direktorat Jenderal Pendidikan Tinggi.

Djahiri, A. K. (1985). Strategi Pengajaran Afektif-Nilai-Moral VCT dan Games dalam VCT. Bandung. FPIPS.

Fairizah Haris. (2013). Penerapan Model Pembelajaran VCT (Value Clarification Technique) untuk Meningkatkan Kesadaran Nilai Menghargai Jasa Pahlawan pada Siswa Sekolah Dasar

Ghanis Putra, Nunuk Suryani, Suharno. (2013). Pengembangan Model Internalisasi Nilai Karakter dalam IPS (Ilmu Pengetahuan Sosial) Melalui VCT (Value Clarification Technique) di SMA (Sekolah Menegah Pertama) Se Solo Raya.

Hamid Hasan, Said. (2010). Baham Pelatihan Penguatan Metodologi Pembelajraan Berdasarkan Nilai-Nilai Budaya untuk Membentuk Daya Saing dan Karakter Bangsa Pengembangan Pendidikan Budaya dan Karakter Bangsa, Jakarta: Kementrian Pendidikan Nasional Badan Penelitian dan Pengembangan Pusat Kurikulum

Kosasih. (2004). Evaluasi Pendidikan. Surabaya: Usaha Nasional.

Kusnadi, Rohani. (.2014). Pembelajaran Berbasis Nilai Karakter

Panitia Sertifikasi Guru. (2012). Bahan Ajar Proses Belajar Mengajar IPS

Rachim, Diana. (2011). Penerapan Model Pembelajaran Vct (Values Clarification Technique) Berbantuan Media VCD untuk Meningkatkan Hasil Belajar Pendidikan Kewarganegaraan Pada Siswa Kelas V Semester 2 SD N.14 Sesetan Kecamatan Denpasar Selatan Tahun Pelajaran 2010/2011.

Sanjaya, Wina. (2010). Kurikulum Dan pembelajaran. Jakarta:Kencana Perdana Media Group.

Sumaatmadja, Nursid. (2001). Metode Pembelajaran Geografi. Jakarta :Bumi Aksara:

Taniredja,Tukiran, Dkk. (2011). Model-Model Pembelajaran Inovatif. Bandung : Alfabeta.

Tim Penyusun Kbb. (2008). Kamus Besar Bahasa Indonesia, Jakarta: Pusat Bahasa Departemen Pendidikan Nasional

Undang-Undang No.20. (2003). Tentang Tujuan Pendidikan Nasional. Jakarta: Sekretaris Negara RI.

Vety Fitriani, Dadang Sundawa. (2016). Penerapan Model VCT (Value Clarification Technique) dengan Menggunakan Media Cerita Daerah Dalam Pembelajaran Pendidikan Kewarganegaraan untuk Meningkatkan Karakter Peserta Didik

Winataputra, Dkk. (2006). Materi Dan Pembelajaran Pkn Sd. Jakarta: Pusat Penerbitan Universitas Terbuka

Heri, Rahyubi. (2012). Teori-Teori Belajar dan Aplikasi Pembelajaran Motorik. Bandung: Nusa Media 